\title{
The Breakthrough In Enforcing The Traffic Law Through E-ticket
}

\author{
Eldi Nasali \\ \{eldinasali86@gmail.com\} \\ Doctor of Law, Universitas Jayabaya, Jakarta, Indonesia
}

\begin{abstract}
The Electronic Traffic Law Enforcement (ETLE) that employs Automatic Number Plate Recognition (ANPR) camera is able to detect the number plates automatically and record the evidence of violations. However, this system has several obstacles, including the possibility of violators that do not match the identity in the Vehicle Registration Certificate (STNK) because the vehicles have been sold to other people or the use of rented vehicles. In this case, a legal problem occurs, inhibiting the law from being implemented. This research discusses how the law should regulate this occurrence to make ETLE implementation effective and efficient. This normative legal research regarded primary, secondary and tertiary legal materials. It was found that the ineffectiveness of ETLE law enforcement is due to unclear rules when the legal subjects who violate traffic regulations and the owner of STNK do not match. It is suggested that clear regulations are made immediately to provide alternative solutions regarding criminal responsibility in ETLE implementation.
\end{abstract}

Keywords: Electronic Traffic Law Enforcement; Law Enforcement, Traffic

\section{Introduction}

Due to the high rate of Indonesia's traffic violation, the Indonesian government and the police have come up with a policy to renew the ticket system. This is driven by the fact that the ticket system is still conventional and insufficient to discipline traffic violation offenders. Also, the old method has been proven ineffective to address classic problems such as illegal fees in traffic law enforcement. The problem is so vivid that the government reconfigure its penal policy by implementing an electronic ticketing system known as E-Tilang in Indonesia.

Through this E-ticketing policy, the public services can be more effective, efficient, transparent and accountable in realizing good governance. This is in line with the constitutional mandate of Article 34 paragraph (3) of the 1945 Constitution, which explains that the state is responsible for providing proper health facilities and public service facilities. Conceptually, the E-Tilang policy is a form of ticket digitalization using the current sophisticated technology. Technically speaking, this system allows the offender to be absent before the judge.

The application of E-Tilang is expected to reduce traffic violations. This method employs CCTV camera tickets or known as Electronic Traffic Law Enforcement (E-TLE). This program proceeds by installing surveillance cameras at the traffic lights. E-TLE will capture images or photos of vehicles that exceed speed limits. Then, the images will be integrated into the police system and will be followed up by sending a ticket to the offender. If the offender does not respond, their vehicle registration card (Surat Tanda Nomor Kendaraan-STNK) will be 
blocked by the officer. Furthermore, the officer will give a physical blue ticket to the offender and message notification of their BRIVA E-Tilang to their mobile numbers about the payment detail code.

The legal basis for E-TLE is Law Number 22 of 2009 concerning Road Traffic and Transportation (Lalu Lintas dan Angkutan Jalan-LLAJ) and Government Regulation Number 80 of 2012 concerning Procedures for Inspection of Motor Vehicles on the Road and Enforcement of Traffic and Road Transportation. Article 272 of the LLAJ states that electronic equipment, which has all been integrated into the NTMC data centre (National Traffic Management Center (Pusat Pengendali Lalu Lintas Nasional Kepolisian), can support the activity of prosecuting violations of Road Traffic and Transportation.

Understanding the construct of regulation and the legal scope of traffic law is appealing to be studied further. In the current context of the Indonesian Police, the initiation of E-TLE is a breakthrough to enforce traffic law. It has been implemented in various regional police across Indonesia. Against that background, the focus of this paper is to identify the issues of law enforcement in the traffic law aspect concerning the E-TLE and how its condition can improve E-TLE in the future.

\section{Research Methods}

This study applied a normative juridical approach by observing the legal concept of the constitution. The basis of this study is (1) the primary legal source that is taken from the basic norm or the principle, basic regulation, and constitution regulation, and (2) the secondary legal source that provides further elaboration of the primary source. The latter usually legal literature, such as journals and case study reports, which are relevant to this study. All data are from library study, and its rendition of analysis is provided in the form of qualitative description to address the issues raised in this paper.

\section{Results and Discussion}

E-Tilang is a form of ticketing for traffic violations using the Electronic Traffic Law Enforcement system (E-TLE). E-TLE is a breakthrough designed to ameliorate the quality of traffic safety, reducing the fatality rate of accident victims, maintaining security, safety, order and ease of traffic. Further, it also aims to build a culture of order and transparency to provide the best service to community members.

E-TLE is often defined as an effective traffic law enforcement system, using electronic technology in the form of an ANPR (Automatic Number Plate Recognition) camera, which can automatically detect vehicle plates, record them, and store evidence of such violations In its implementation, E-TLE is capable of detecting ten traffic violations: traffic light and traffic sign violations, odd-even plate violation, unfastened seatbelts, driving while on a mobile device, speeding at threshold limit, driving against the traffic, riding without helmets, driving with revoked vehicle registration, and improper lane usage.

Lawrence Meir Friedman proposed that the law's success depends on three notionssubstance, legal structure, and legal culture. First, the substance is defined as the by-products of legal reasonings by the people who belong to a legal system. On the other hand, the legal 
structure is defined as a structural system that determines whether or not the law is implemented correctly. Law enforcement is expected to carry on their duties and responsibilities with integrity and independence without external influence of government power and other influences. The law cannot be executed by those who are not credible, incompetent, and dependent. A good statutory depends on the law enforcement with the criteria above; otherwise, it is merely wishful thinking. The improper execution of law is usually attributed to the weak mentality among law officers. Lastly, legal culture is defined as the human attitude towards the law, belief system, value, thought, and aspirations. Legal culture is the nuance of social conditioning, and the strength of legal culture is strongly associated with the legal conscious in a society.

The higher the legal consciousness, the more plausible it will be to create an excellent legal culture that can change the mindset of people towards law. Put it simply, the level of obedience among the people towards the law is one indicator of how functional a law is. Obedience is measured by how the law is used, abused, or neglected. The regulation regarding the road traffic, transportation information, and communication system become the police's responsibility, including information and communication subsystem of road traffic and transportation (LLAJ) managed by the regional or central government according to their scope of jurisdiction. As a result, while the national police are appointed as the control centre manager, the regional government and the supervisor of LLAJ are obliged to integrate their data into information and communication system for traffic and road transportation.

Even with the excellent application of the E-TLE, that does not exempt it from any issue. In E-TLE, the ticket is delivered to the offender as a written statement to appear in court. What is recorded by the camera sensor is a number plate which is then read by the Automated Number Plate Recognition (ANPR) software to undergo physical matching of the vehicle and the data from the identity database of the Department of Motor. This E-TLE working mechanism raises the possibility that traffic offenders are not the legal owner of the vehicle that they use when committing a traffic violation.

To overcome this problem, it is necessary to change the principle of criminal responsibility in applying ETLE to the principle of vicarious liability to transfer the liability to the perpetrators of the traffic violation. Juridically, both the Criminal Code and the Road Transportation Traffic Act (UULLAJ) has not adopted the vicarious liability principle. What is still in practice is the positive law that goes by the principle of no crime without error (geen straf zonder schuld). In E-TLE, the prosecuted person is the person whose name is listed in the vehicle registration so that the E-TLE does not merely prosecute the offender, although, in overloading violations, the driver is responsible for the violations.

The idea of applying the vicarious liability principle requires juridical and sociological legitimacy as a form of protection and prevention. It also needs to build a culture of orderly traffic. When ETLE is applied, one of the consequences for the owner is to make them cautious with the decision to lend or allow another individual to operate their vehicle.

Variations in the information and communication subsystems of LLAJ at the level of the Central Government (in this case, the advisor at LLAJ) and Local Governments, both in terms of interface and content management system, indicate that there has been no data integration, both at the level of the Central Government (LLAJ stakeholders) and regional government as mandated by the traffic and motor vehicle Law. Indeed, this bears a new challenge for further implementation of the E-TLE. Suppose E-TLE is to be implemented in all regions of Indonesia. In that case, it is necessary to immediately provide a control centre for the Traffic and Road Transportation Information System, equipped with comprehensive data integration from and at the central and regional government levels.. 
Currently, there is no sui generis regulation regarding ETLE. Referring to Government Regulation 80 of 2012, there is a delegatie provisio to the Chief of Police to formulate further provisions regarding the prosecution of violations based on electronically recorded evidence as regulated by the Regulation of Chief Indonesian National Police. However, until now, no such matter arises regarding prosecution of violations based on the electronically recorded evidence, even if they can regulate it under the auspice of the principle of the bij de wet geregeld by using electronically recorded evidence to prosecute traffic offenders.

So far, the National Police has started drafting a Regulation of the Chief of the National Police of the Republic of Indonesia regarding the prosecution of violations based on electronically recorded evidence since 2018. However, until now, the regulation draft has not been ratified and has no binding legal force. This is undoubtedly counterproductive in the spirit of postponing the enforcement of traffic violation norms based on records of electronic equipment, which only took effect 1 (one) year from the enactment of PP 80 of 2012 . The postponement of the norms in Article a quo should be momentum to prepare the facilities, infrastructure and legal institutions needed in implementing ETLE.

\section{Conclusion}

Law enforcement of traffic violations using ETLE has become a new milestone to digitalization as part of reforming the conventional legal prosecution. So far, traffic law enforcement has gone from catching offenders red-handed with the naked eye to utilizing cameras with intelligence software along the way. The expected condition is further improvement in data synchronization at the main Control Centre, with strong integration with the data from regional government across all Indonesian provinces. To realize this vision, the Indonesian Police Chief must mandate several regulations as the patron to all regional police to strengthen the traffic law enforcement by using electronically recorded evidence.

\section{References}

[1] Ahmad, H. Abu \& Cholid Narbuko (2002), Metodelogi Penelitian, Jakarta: Bumi Angkasa.

[2] Budhijanto, Danrivanto (2014) Peran Hukum Telekomunikasi terhadap Implikasi Konvergensi Teknologi Informasi dan Komunikasi, Jurnal Dinamika Hukum Volume 14 Nomor 1.

[3] Direktorat Lalu Lintas Polda Metro Jaya, "Electronic Traffic Law Enforcement" Dirlantas Polda Metro Jaya, Jakarta, Juli 2018

[4] Fines Fatimah dan Barda Nawawi Arief, Pertanggungjawaban Pengganti (Vicarious Liability) Dalam Kebijakan Formulasi Hukum Pidana di Indonesia. https://media.neliti.com/media/ publications/109433-ID-pertanggungjawaban-pengganti-vicarious-l.pdf accessed on 8 April 2021, at 21.00 wib.

[5] Friedman, Lawrence M. (2009) Sistem Hukum, Bandung: Nusa Media, 2009.

[6] Government Regulation Number 80 of 2012 on Procedures for Inspection of Motor Vehicles on Roads and Enforcement of Traffic and Road. Transportation Violations.

[7] https://www.itworks.id/38187/apa-itu-tilang-elektronik-atau-electronic-traffic-law-enforcementetle.html, accessed on 8 April 2021, at 21.00 wib

[8] Law Number 22 of 2009 on Road Traffic and Transportation

[9] Lestari, Ika Devi., Ditasari Wardani, \& Sri Wibawani, (2020) Inovasi Program Electronic Traffic Law Enforcement (E-TLE) Di Kota Surabaya, Public Administration Journal Of Research Volume $2(2)$. 
[10] Perdana, Wisnu Amri Panahatan Sihotang \& Tri Mulyani Pelaksanaan Electronic Traffict Law Enforcement Di Wilayah Hukum Kota Semarang. http//repository.usm.ac.id, jurnal, accessed on 8 April 2021, at 21.00 wib.

[11] Soekanto, Soerdjono (1996) Pengantar Penelitian Hukum, Jakarta: UI Press, 1996. 